\title{
Schedule of German Broadcasts on Compact Disk Insert
}

\begin{tabular}{|c|c|c|c|}
\hline Track & Broadcaster & Date of Recording & Synopsis of content \\
\hline I & William Joyce & I4 January $194^{\circ}$ & 'Germany Calling. \\
\hline 2 & William Joyce & 20 January 1940 & Fate of British cruiser Exeter. \\
\hline 3 & William Joyce & 21 January 1940 & $\begin{array}{l}\text { Germany denies British and } \\
\text { French claims that she has } \\
\text { designs on the Balkans. }\end{array}$ \\
\hline 4 & William Joyce & I8 February I940 & $\begin{array}{l}\text { Churchill's message to Captain } \\
\text { of HMS Cossack after } \\
\text { Altmark episode, 'the height of } \\
\text { cynicism'. }\end{array}$ \\
\hline 5 & William Joyce & 27 February 1940 & $\begin{array}{l}\text { English momen mearing hats of } \\
\text { tin, to protect them from } \\
\text { splinters from German bombs. }\end{array}$ \\
\hline 6 & $\begin{array}{l}\text { New British } \\
\text { Broadcasting } \\
\text { Station }\end{array}$ & 5 March 1940 & $\begin{array}{l}\text { Disorganisation and chaos of } \\
\text { evacuation of children classic } \\
\text { example of confusion. }\end{array}$ \\
\hline & & & $\begin{array}{l}\text { Popularity of German radio } \\
\text { due to its truthfulness. }\end{array}$ \\
\hline 7 & William Joyce & 9 April 1940 & $\begin{array}{l}\text { Operations concerning } \\
\text { occupation of Denmark and } \\
\text { Norway have proceeded to } \\
\text { plan. German minister in } \\
\text { Norway has warned that } \\
\text { resistance is futile. }\end{array}$ \\
\hline 8 & William Joyce & I June $194^{\circ}$ & $\begin{array}{l}\text { Belgian surrender- } \\
\text { commentary. }\end{array}$ \\
\hline 9 & William Joyce & June 1940 & $\begin{array}{l}\text { Plutocratic caste who provoked } \\
\text { mar are abandoning 'doomed' } \\
\text { island. }\end{array}$ \\
\hline Io & William Joyce & I June $194^{\circ}$ & $\begin{array}{l}\text { 'Bloody and battered } \\
\text { fragments' of the BEF drift } \\
\text { back in wreckage to England. }\end{array}$ \\
\hline II & William Joyce & I June 1940 & $\begin{array}{l}\text { Churchill an 'unclean and } \\
\text { miserable figure'. }\end{array}$ \\
\hline 12 & William Joyce & I8 September 1943 & $\begin{array}{l}\text { Commentary on rescue of } \\
\text { Mussolini. }\end{array}$ \\
\hline
\end{tabular}


I3 Eduard Roderich Dietze

I4 Margaret Joyce

II February 1944

I5

I6

I7 Edward Bowlby

I8 Messages from

British Prisoners

in Germany

I9 John Amery

20 Edward Bowlby

2I Workers'

Challenge

22 William Joyce

23 William Joyce

24 William Joyce

29 August 1944

Unidentified

Unidentified
8 September 1943

Commentary on the fall of Italy. America acquires body and soul of England from Churchill.

Commentary on unemployment problem in the democracies 'What on earth is this war being fought about?' Commentary on 'invasionitis' - Jems profit from armaments boom.

Russian rule - Bolsheviks bring unemployment, terror and fems.

3I August 1944 Terror raids by $R A F$ mill be avenged by total war effort.

I September I944 Messages from British prisoners-of-par in Germany.

I6 September 1944 Anti-German resistance no more than femish-run terrorists.

4 September 1944 The Femish problem.

2 December 1944 What porkers could have done with money pasted on par.

Savage hoards of Bolshevism threaten European civilisation. American domination of Canada.

Foyce's last drunken valedictory talk - unbroadcast. 